\title{
UTILIZATION OF PALM OIL AND ELECTRIC POWER PLANT FLY ASH WASTE MATERIAL AS A CLAY REPLACEMENT IN BRICKS
}

\author{
Masni A Majid ${ }^{1}$, Mohd Fazdli Abdul Manaf ${ }^{2}$
}

\author{
Faculty of Civil and Environmental Engineering, University of Tun Hussein Onn Malaysia, \\ 86400 Parit Raja,Batu Pahat, Johor, Malaysia \\ masni@uthm.edu.my¹, mfazdli@jkr.gov.my²
}

Keywords: Fly Ash, industrial waste, clay replacement, water absorption, compressive strength

\begin{abstract}
In this study bricks samples were produced containing substituent from palm oil and electric power plant fly ash. These waste products are used to replace the natural ingredient in the manufacturing of brick clay namely as clay. At the present, the world's natural resources are decreasing so many alternative actively pursued to ensure that the natural ingredients will remain unchanged for the use of the more significant and worthwhile. In this study, some suggestions have been proposed where the using of fly ash as a clay replacement materials in the percentage of $20 \%$, $40 \%$ and $60 \%$. The several laboratory experiments was carried out, where the high compressive strength with $20 \%$ of fly ash replacement is $15.5 \mathrm{~N} / \mathrm{mm}^{2}$ while for the $20 \%$ of power plant fly ash replacement provide a compressive strength of $103 \mathrm{~N} / \mathrm{mm}^{2}$. For optimum water absorption, the rate is $17.05 \%$ which is from $20 \%$ of palm oil fly ash replacement while for brick from $60 \%$ power plant fly ash, the rate of water absorption is $4.96 \%$. Therefore, this study can contribute to recycling the industrial waste material as a replacement material in brick in Malaysia.
\end{abstract}

\subsection{Introduction}

Construction field has contributed a lot to many advancement of the country in this era, not only in Malaysia but also in abroad. Construction field can be seen in terms of demand for residential construction, building offices, business premises etc are constantly increasing for the country to develop and strengthen the economy. The worldwide annual production of bricks is currently about 1391 billion units and the demand for bricks is expected to be continuously rising. It is also noted that there is a shortage of clay in many parts of the world. In this study the use of industrial waste in the production of bricks is one step to reuse the industrial waste. Problems related to industrial waste is a serious concern in our country. Therefore, measures should be taken to ensure that industrial waste can be recycled to produce something useful. With the recycling waste from industry, then, it can be some way helping the authorities to manage the wastes $[1,2]$.

\subsection{Literature Review}

A number of previous research have used as a guide to select a variety of information related to this study. Several studies conducted to show that the use of fly ash as a replacement material for producing bricks. The following are some of the earlier studies were conducted using fly ash as a replacement material for producing bricks.

i. $\quad$ The study conducted by Chen et al. al., 2011[3], a study of mixtures of ceramic powder, fly ash and clay to has been made to produce bricks. In his study, the researcher used only 0-8 $\%$ fly ash. Among the mix made, it is found that $6 \%$ fly ash with $20.36 \mathrm{MPa}$ and $17.79 \%$ is the best in terms of compressive strength and water absorption rate compared to other mixtures. 
ii. Ling ling et al. [4] investigated the production of fired bricks by using class F fly ash to replace clay at high volume ratios. Brick samples were prepared by mixing fly ash and clay at designed proportion, casting the mixture into bricks, drying the bricks at ambient condition for 2 days, at $60^{\circ} \mathrm{C}$ for $4 \mathrm{~h}$ and at $100^{\circ} \mathrm{C}$ for $6 \mathrm{~h}$, and firing the dried bricks in an electric furnace at $100{ }^{\circ} \mathrm{C} / \mathrm{h}$ below $500{ }^{\circ} \mathrm{C}, 50{ }^{\circ} \mathrm{C} / \mathrm{h}$ from $500{ }^{\circ} \mathrm{C}$ to highest temperature $\left(1000,1050\right.$, or $\left.1100{ }^{\circ} \mathrm{C}\right)$, and at the highest temperature for $8 \mathrm{~h}$. In the research, several samples were made between $0 \%, 50 \%, 60 \%, 70 \%$ and $80 \%$ fly ash used in replacing clay to produce bricks. The results obtained from the study found that a mixture of $50 \%$ fly ash gave the highest compressive strength of $98.5 \mathrm{MPa}$ and $17.62 \%$ rate of diffusion of water.

iii. A study conducted by Chou et al., (2006)[5,6], has made a study of class F fly ash in bricks. Researchers have used a total of $0 \%-60 \%$ fly ash content in the volume of the brick. Major international mix was made using fly ash in the study of them $0 \%, 20 \%, 40 \%$ and $60 \%$ to replace clay bricks in production. For compression test, $12.4 \mathrm{MPa}$ was obtained with $13.8 \%$ of water absorption rate. Both of these test results obtained from a mixture of $40 \%$ fly ash used in replacing the clay content in the production of bricks. The result is the highest results obtained from the four infusions made.

\subsection{Methodology}

\subsection{Preparation of samples}

Raw materials that have been used in this research were clay, palm oil fly ash and electric power plant fly ash as replacement materials. A total of 63 clay bricks with dimension $25 \mathrm{~mm}$ x $25 \mathrm{~mm} \times$ $100 \mathrm{~mm}$ have been produced. All samples were made using a suitable machine. One set of clay brick were also been produced as control specimens. The samples have been tested for 7 and 28 days respectively.

\subsection{Determination of water absorption}

Brick specimens used in this research were prepared based from guidelines stipulated from Malaysia Standards 76: Part 2:1976. Each batch of clay brick ratio will undergo water adsorption testing. This test was needed to determine the capability of clay brick to water absorption. The method of determination water absorption capacity is by the weight of surface-dry sample after it has been soaked for 24 hour and dried in the oven. The difference in weight, expressed as a percentage of the dry sample weight, is the absorption capacity. Result for each sample for every batch will be compared with controlled sample.

\subsection{Determination of compressive strength}

Compressive strength is the primary physical property of clay brick. It is also a fundamental property used for quality control purposes for clay brick with fly ash. Compressive strength can be defined as the ability of clay brick specimen to sustain the axial load. In this study, all clay brick with fly ash and control clay brick samples will be tested to determine its compressive strength at 7 and 28 days. All specimens were tested using compression machine until its failure. Results for each sample for every batch will be compared with controlled sample.

\subsection{Determination of density}

The density of both fresh and hardened control clay brick and clay brick with fly ash is important as it can gives an idea related to clay brick durability, strength and resistance to permeability. 
Hardened clay brick density is determined either by simple dimensional checks, followed by weighing and calculation or by weight in air. In this research, a simple method to determine the density of lightweight concrete sample was using the formula given below:

$$
\text { Density }=\frac{\text { Weight of Sample }(\mathrm{Kg})}{\text { Volume of Sample }(\mathrm{m} 3)}
$$

\subsection{Atterberg Limits}

This experiment is to determine plastic limit (PL), liquid limit (LL) and plasticity index (PI) value of soil sample. Plastic limit, $\mathrm{Wp}$ are defined as water content that is required in a soil sample in order to be excessively dry to plastic state in the plastic limit experiment. Liquid limit, WL defined as moisture content of soil liquid level before the plastic stage. Liquid limit defined as moisture content at depths of $20 \mathrm{~mm}$ cone penetration within 5-second penetration. Plastic Index, PI defined as numerical difference between liquid limit with plastic limit

\subsection{Results and Discussions}

\subsection{Compressive Strength}

Figure 4.1 shows a compressive strength of $20 \%$ brick with fly ash. Based on laboratory testing it was found that the bricks $20 \%$ containing fly ash of power plants have the highest compressive strength compared to the control bricks and brick fly ash palm oil, where the compression strength is $103 \mathrm{~N} / \mathrm{mm}^{2}$ for the power plant fly ash bricks. For brick controls specimens the compression strength of $63.40 \mathrm{~N} / \mathrm{mm}^{2}$ and $15.47 \mathrm{~N} / \mathrm{mm}^{2}$ for palm oil fly ash brick. In Figure 4.2 shows a compressive strength of $40 \%$ brick with fly ash. Based on laboratory testing it was found that the bricks $40 \%$ containing fly ash of power plants have the highest compressive strength compared to the control bricks and brick fly ash palm oil, where the compression strength is $99.10 \mathrm{~N} / \mathrm{mm}^{2}$ for the power plant fly ash bricks. For brick controls specimens the compression strength of $63.40 \mathrm{~N} / \mathrm{mm}^{2}$ and $7.10 \mathrm{~N} / \mathrm{mm}^{2}$ for palm oil fly ash brick. Figure 4.3 shows a compressive strength of $60 \%$ brick with fly ash. Based on laboratory testing it was found that the bricks containing $60 \%$ fly ash of power plants have the highest compressive strength compared to the control bricks and brick fly ash palm oil, where the compression strength is $91.80 \mathrm{~N} / \mathrm{mm}^{2}$ for the power plant fly ash bricks. For brick controls specimens the compression strength is $63.40 \mathrm{~N} / \mathrm{mm}^{2}$ and $1.30 \mathrm{~N} / \mathrm{mm}^{2}$ for palm oil fly ash brick.

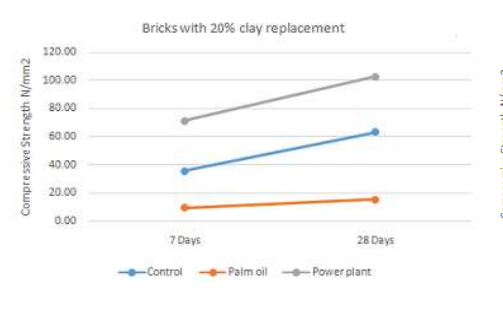

Figure 4.1

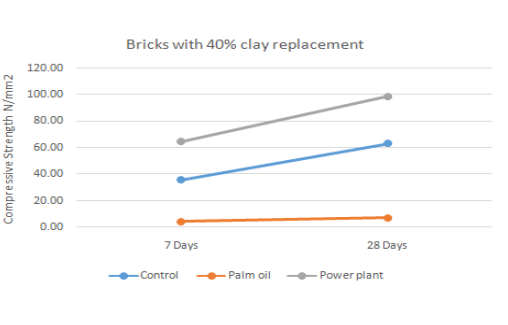

Figure 4.2

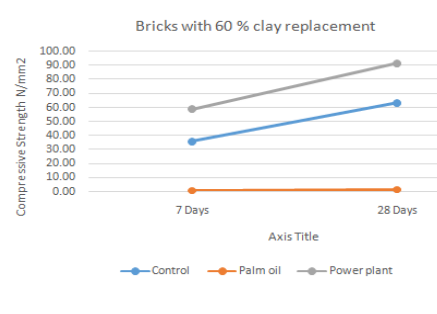

Figure 4.3

\subsection{Water Absorption}

Figure 4.4 shows the rate of water absorption for control brick and brick containing $20 \%$ of fly ash. All samples bricks that have reached the age of 28 days will undergo diffusion rate. The rate of water diffusion for controlled bricks is $13.48 \%$ while for the brick samples containing fly ash of oil 
palm is $17: 05 \%$ and for bricks samples containing power plant fly ash was by $7.45 \%$. Figure 4.5 shows the rate of water absorption for control brick and brick containing fly ash $40 \%$. The rate of water diffusion for controlled bricks samples is $13.48 \%$ while the brick samples containing oil palm fly ash replacement is $22.88 \%$ and for samples containing power plant fly ash was by $5.59 \%$. While Figure 4.5 shows the rate of water absorption for control brick and brick containing $60 \%$ of fly ash. For controlled bricks samples, the rate of diffusion of water is $13.48 \%$ while the brick samples containing oil palm fly ash replacement, the water absorption rate is $46.59 \%$ and for samples containing power plant fly ash brick replacement of was by $4.96 \%$.

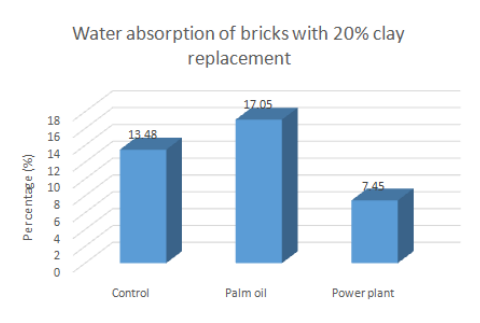

Figure 4.4

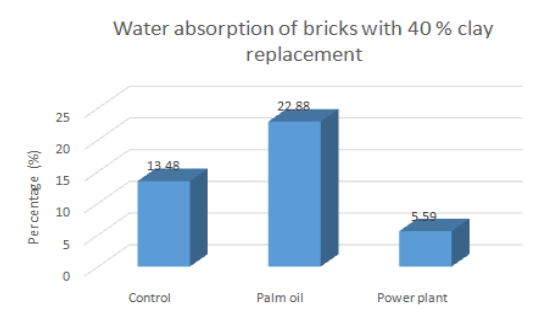

Figure 4.5

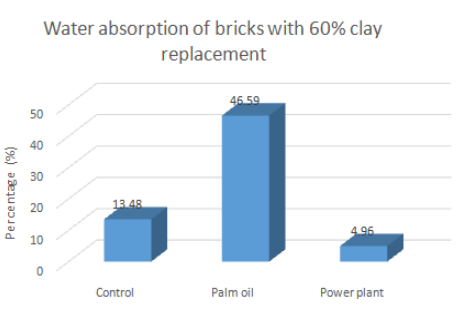

Figure 4.6

\subsection{Density of Clay Brick}

Figure 4.7 shows about density of clay brick. The density of clay bricks produced will affect the compressive strength of the bricks. Based on figures, it was found that the density of controlled bricks is quite similar to the bricks that containing fly ash. According to the data, it is shows that the highest density comes from bricks with power plant fly ash, followed by control bricks. Bricks containing palm oil fly ash shows the lowest results of density. This indicates that the bricks containing palm oil fly ash is lighter than control bricks and bricks with power plant fly ash.

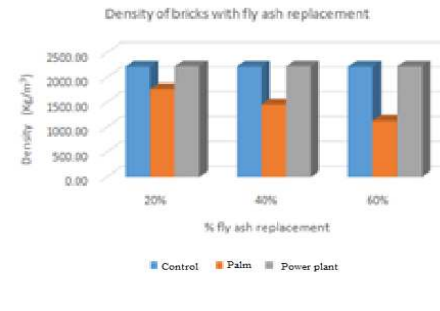

Figure 4.7

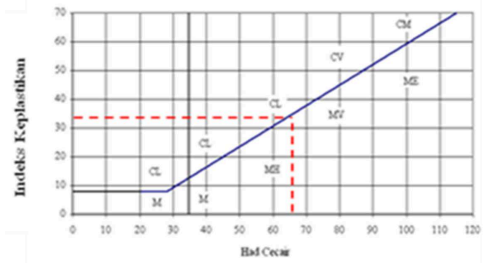

Figure 4.8

\subsection{Atterberg Limits}

From the experiment, the liquid limit, LL for clay is $54.14 \%$ and the value shows that the clay has highly plasticity. For plastic limit, the PL value is $28.81 \%$. The plastic index value was IP $=$ LL $\mathrm{PL}=25.33 \%$. Refers to plastic index chart (Figure4.8). The soil sample was classified as clay silt with high plasticity $(\mathrm{MH})$.

\subsection{Conclusions}

Based on the study, researchers found that the power plant fly ash can be used to replace the clay in bricks production. From the study, the volume of clay that can be replaced by the power plant fly ash is until $60 \%$. Bricks samples that have been tested were obtained to meet the standards by MS 76: Part 2:1976. Therefore the bricks with power plant fly ash clay replacements were suitable for 
marketed in Malaysia due to the high compressive strength and density obtained through experiments. It was found that the bricks meet the class as stated by the standard. For clay brick with power plant fly ash can be classify as engineering brick class 2 and clay brick with palm oil fly ash can be classify as ordinary brick.

\section{Acknowledgement}

This work was supported by the Universiti Tun Hussein Onn Malaysia in term of materials, equipment and tools and special thanks to those who helps in this research.

\section{References}

[1] Lippiatt BC. BEES 4.0 - Building for environmental and economic sustainability. Technical manual and user guide. NISTIR 7423; 2007

[2] Lianyang Zhang. Production of bricks from waste materials - A review, Construction and Building Materials 47 (2013) 643-655

[3] Chen Y, Zhang Y, Chen T, Zhao Y, Bao S. Preparation of eco-friendly construction bricks from hematites tailings. Constr Build Mater 2011; 25:2107-11.

[4] Lingling X, Wei G, Tao W, Nanru Y. Study on fired bricks with replacing clay b fly ash in high volume ratio. Constr Build Mater 2005;9:243-7.

[5] Chou MI, Patel V, Laird CJ, Ho KK. Chemical and engineering properties of fired bricks containing 50 per cent of class F fly ash. Energy Sources 2001;23:665-73.

[6] Chou M I, Chou SF, Patel V, Pickering MD, Stucki J.W. Manufacturing fired brick with class F fly ash from Illinois basin coals. Combustion by product of recycling consortium. Project number 02-CBRC-M12. Final report; 2006. 